\title{
Bacillus pumilus BpCRI 6, a promising candidate for cellulase production under conditions of catabolite repression
}

\author{
Kotchoni O.S..$^{1 *}$, Shonukan O.O. ${ }^{1}$ and Gachomo W.E. ${ }^{2}$ \\ ${ }^{1}$ Department of Microbiology, Faculty of Science, Obafemi Awolowo University, Ile-Ife, Osun State, Nigeria. \\ ${ }^{2}$ Institute for Plant Diseases, University of Bonn, Nussallee 9, D-53115 Germany.
}

Accepted 16 May 2003

\begin{abstract}
Cellulose degrading organisms have been used for the conversion of cellulolytic materials into soluble sugars or solvents in several biotechnological and industrial applications. In this report, a mutant of Bacillus pumilus was obtained after chemical mutagenesis and screened for cellulase production. This mutant named BpCRI 6 was selected for its ability to produce cellulase under catabolite repression. Cellulase yield by BpCRI 6 was four times higher than that of the wild type under optimum growth conditions ( $\mathrm{pH} 6.5,25^{\circ} \mathrm{C}$ and $\left.\mathrm{Ca}^{2+} 1 \mathrm{mM}\right)$. In shaking flask cultures, production of cellulase by the wild type was completely repressed in the presence of $25 \mathrm{mM}$ glucose, while BpCRI 6 strain still exhibited a residual cellulase production of 80 and $40 \%$ at $25 \mathrm{mM}$ and $40 \mathrm{mM}$ of glucose concentrations respectively. The mutant strain is stable and grows rapidly in liquid and solid media. Under conditions of catabolite repression ( $40 \mathrm{mM}$ of glucose), the production of cellulase by this mutant is particularly significant when compared to Trichoderma reesei a well-known cellulase producer, which is under control of end-product inhibition. This is the first report of a successful catabolite repression insensitivity of cellulase production by a mutant of $B$. pumilus.
\end{abstract}

Key words: Cellulase, Bacillus pumilus, BpCRI 6, Catabolite repression.

\section{INTRODUCTION}

The potential use of cellulosic materials as renewable sources of carbon was recognized and accelerated after cellulose degrading enzymes or cellulases were identified (Bhat and Bhat, 1997). Up to date, the production of cellulase, which is one of the key enzymes for cellulose biodegradation has been found to be the most expensive step. This step takes approximately $40 \%$ of the total cost during ethanol production from cellulosic biomass (Solomon et al., 1997). The high cost of the enzyme production limits its industrial use in the production of soluble sugars. Therefore, several approaches including chemical mutations, UV irradiations and genetic engineering to obtain enhanced cellulase producing strains have been given a high priority in the last decade (Labudova and Farkas, 1983; Kotchoni and Shonukan, 2002). The enzymatic hydrolysis of cellulosic materials is a slow and complex reaction. This reaction correlates

\footnotetext{
${ }^{*}$ Corresponding author; Kotchoni O.S.,Tel: + 49-228-739581, Fax: + 49-228-732689, E-mail: kotchoni@uni-bonn.de

† Current Address: Department of Plant Molecular Biology, Institute of Botany, University of Bonn, Kirchallee 1, D-53115 Bonn, Germany.
}

with the level of cellulose crystallinity (Weimer and Weston, 1985). Nevertheless, strains that are genetically improved for high level of cellulase production have been successfully used in a number of applications including animal feed, pharmaceutical and textile industries (Aristidou and Penttilä, 2000; Oksanen et al., 2000). Cellulases and hemicellulases have been evaluated for their ability to beneficially modify pulp and paper characteristics (Kibblewhite and Clark, 1996; Espana et al., 1998; Lin et al., 1995, Roncero et al., 2000; Suurnäkki et al., 2000; Torres et al., 2000). Moreover, cellulase treatment of dried pulp seems to increase the relative bonded area of the fibrous paper network, improving some paper properties (Pastor et al., 2001). These are some practical examples promoting the usefulness of the enzyme.

Although a large number of microorganisms are capable of degrading cellulose, only few of them produce significant quantities of cell-free cellulase capable of completely hydrolyzing crystalline cellulose in vitro. Cellulases for native cellulose are commercially produced only with strains of the fungus Trichoderma Iongibrachiatum (formerly Trichoderma reesei or T. viride) (Schwarz, 2001). Recently a few bacteria (Clostridium 
thermocellum, Ruminococcus albus and Streptomyces sp.) and actinomycetes (Thermoactinomyces sp., Thermomonospora curvata and Streptomyces sp.) have also been reported to produce cellulase (Lamed and Bayer, 1988; Ohara et al., 2000). However, pure cellulases from bacteria have not yet been commercially produced and standardized enzyme preparations are not available. Moreover, the production of cellulase in most of these organisms is under the control of catabolite repression.

Our laboratory has been interested in the molecular regulation of cellulase synthesis in various microorganisms with the aim of isolating extracellular cellulase producers free from end-product inhibition. The use of Bacillus pumilus has been reported in industry for alkaline protease production (Feng et al., 2001), in environmental decontamination of dioxins (Hong et al., 2001), and recently in baking industry (Nuyens et al., 2001). However, little is known on its ability to produce cellulase. In our previous study we described a chemical mutagenesis affecting the synthesis of cellulase in $B$. pumilus. We used a rapid screening system, to isolate and evaluate the ability of independent mutants that secrete significant amounts of cellulase (Kotchoni and Shonukan, 2002). In the current study we present evidence of a selected mutant free from catabolite repression. This mutant named $B p C R I 6$ for $\underline{\text { Catabolite }}$ Repression Insensitive mutant number $\underline{6}$, was found to produce cellulase in presence of high concentrations of glucose. We have discussed here some comparative characteristics of cellulase produced by $B p C R / 6$ strain with some well-known cellulase producers.

\section{MATERIALS AND METHODS}

\section{Organism and growth conditions}

A glycerol stock of the wild type $B$. pumilus used for the source of cellulase synthesis in this work was provided by Omafuvbe (1998). Liquid cultures were made from overnight-incubated single-cells grown on Luria-Bertani (LB) agar plate at $37^{\circ} \mathrm{C}$. In order to avoid studying an inherent heterogeneity of cellulase produced by the mutants or simply cellulase from another variant strain of $B$. pumilus, a single clone was always allowed to grow for three generations using a replica-plating technique before studying its ability to produce cellulase. All cultures and analysis were carried out from the third generation (G3) cells. The standard growth culture (SC) contained (per litre) $0.2 \%(\mathrm{w} / \mathrm{v})$ glycerol as Carbon source, $0.2 \%(\mathrm{w} / \mathrm{v})$ carboxymethyl-cellulose (CMC) or cellobiose as substrates for cellulase synthesis, $10 \mathrm{~g}$ tryptone, $1 \mathrm{~g} \mathrm{~K}_{2} \mathrm{HPO}_{4}, 0.75$ $\mathrm{g} \mathrm{MgSO}_{4}, 0.75 \mathrm{~g} \mathrm{NaCl}$, in a $0.1 \mathrm{M} \mathrm{KH}_{2} \mathrm{PO}_{4}$ buffer $\mathrm{pH}$ 6.0. All chemicals for the medium and different solutions used in this work were from Merk's Company (E. Merk D-6100 Darmstadt, F. R. Germany).

\section{Chemical mutagenesis and Cellulase producing mutants}

The chemical mutagenesis was carried out according to Kotchoni and Shonukan (2002). Ethyl methanesulphonate (EMS) was used as the mutagenic agent. Wild-type cells $(3 \mathrm{ml})$ in the mid-logarithmic phase were centrifuged at $1600 \mathrm{~g}$ for $15 \mathrm{~min}$ at room temperature. The pellet was resuspended in $1 \mathrm{ml}$ normal saline (NS) and a suspension of 20:1 (v/v) of NS/EMS was made. Appropriate dilutions were made and incubated overnight at room temperature to allow mutational segregation. $100 \mu \mathrm{l}$ of the culture was then spread on agar media and incubated overnight at $37^{\circ} \mathrm{C}$. Single mutant clones were further grown in new plates till the third generation. The third generations (M3) of the mutants were replicaplated in new plates containing CMC as sole source of carbon and $1 \%(w / v)$ Congo red. The selection of mutants was based on the diameter of the clear zone surrounding the colonies in Congo red agar plates (Kotchoni and Shonukan, 2002). In such conditions, the cellulase-producing colonies use CMC (the only source of carbon) to grow, which was easily detected as clear zones on a red background.

The wild type and the selected mutants were inoculated into 200 $\mathrm{ml} \mathrm{SC}$ in separate $500 \mathrm{ml}$ Erlenmeyer flasks containing different concentrations of either $\mathrm{CMC}$ or cellobiose. For conditions of catabolite repression, this inoculation process was repeated with increasing concentrations of glucose. The cultures were incubated at $25^{\circ} \mathrm{C}$ while shaking at $250 \mathrm{rpm}$. After 2 hours of growth, $2 \mathrm{ml}$ samples were periodically removed to examine cell growth and cellulase production. The effects of some compounds such as 2,4dinitrophenol (DNP), ethylene diamine tetraacetic acid (EDTA), and $\mathrm{Ca}^{2+}$ on enzyme production under SC conditions were also tested.

\section{Enzyme Assay}

After incubation, cultures were centrifuged at $1600 \mathrm{~g}$ for $15 \mathrm{~min}$ $\left(25^{\circ} \mathrm{C}\right)$ and supernatants were used as source of crude enzymes. The crude enzymes were precipitated from the supernatant using $561 \mathrm{~g}$ of $\left(\mathrm{NH}_{4}\right)_{2} \mathrm{SO}_{4}$ per litre, which is equivalent to $80 \%$ saturation. The precipitation was performed at room temperature $\left(25^{\circ} \mathrm{C}\right)$ and later kept at $4^{\circ} \mathrm{C}$ for $24 \mathrm{~h}$. The precipitates were obtained after centrifugation and then resuspended in $30 \mathrm{ml}$ of $0.1 \mathrm{M}$ phosphate buffer ( $\mathrm{pH}$ 6.5). These were then dialyzed against three changes of the same buffer for $24 \mathrm{~h}$ at $4^{\circ} \mathrm{C}$ to remove traces of $\left(\mathrm{NH}_{4}\right)_{2} \mathrm{SO}_{4}$. The cellulase activity was determined by quantifying the reducing sugars liberated during growth according to the Somogyi-Nelson Method (Somogyi, 1944). One unit of cellulase activity (IU) is defined as the amount of enzyme that liberates one $\mu \mathrm{mol}$ of glucose equivalent per minute. The mixture for the enzyme assay was made of $1: 1$ enzyme:CMC $(0.2 \%(w / v))$ or enzyme:Cellobiose $(0.2 \%(w / v))$, in $0.1 \mathrm{M}$ phosphate buffer $(\mathrm{pH} 6.0)$ and incubated at $45^{\circ} \mathrm{C}$ for $1 \mathrm{~h}$. The enzymatic reaction was stopped by adding one volume of a combined copper and arsenomolybdate reagents (CAR) i.e. $1 \mathrm{ml}$ of CAR for $1 \mathrm{ml}$ of enzyme-substrate solution as described by Somogyi (1944).

\section{Basic characterization of the enzyme activity}

In order to assess the optimum conditions for enzyme activity $(\mathrm{pH}$, temperature and heat stability), we analyzed the effect of a number of biochemical factors on the enzymatic reactions. For the estimation of optimum $\mathrm{pH}$, the enzyme was mixed with substrates at different $\mathrm{pH}$ levels $(\mathrm{pH} 4.0$ to 9.0). These substrates were prepared in two buffer solutions: citrate-phosphate buffer $(0.1 \mathrm{M}$ citric acid, $0.2 \mathrm{M} \mathrm{Na}_{2} \mathrm{HPO}_{4}, \mathrm{pH} 4.0$ to 7.0$)$, and Tris buffer $(0.1 \mathrm{M}$ Tris- $\mathrm{HCl}, \mathrm{pH} 7.5$ to 9.0). For optimum temperature, the enzyme was incubated with substrates for $30 \mathrm{~min}$ at various temperatures between 30 to $90^{\circ} \mathrm{C}$ before assaying for the cellulase activity. For temperature stability, the enzyme was incubated in the standard buffer at different temperatures ranging from 50 to $90^{\circ} \mathrm{C}$ for $15 \mathrm{~min}$ and the tubes were immediately placed in ice for $5 \mathrm{~min}$ before adding the substrates and assaying for the cellulase activity. 

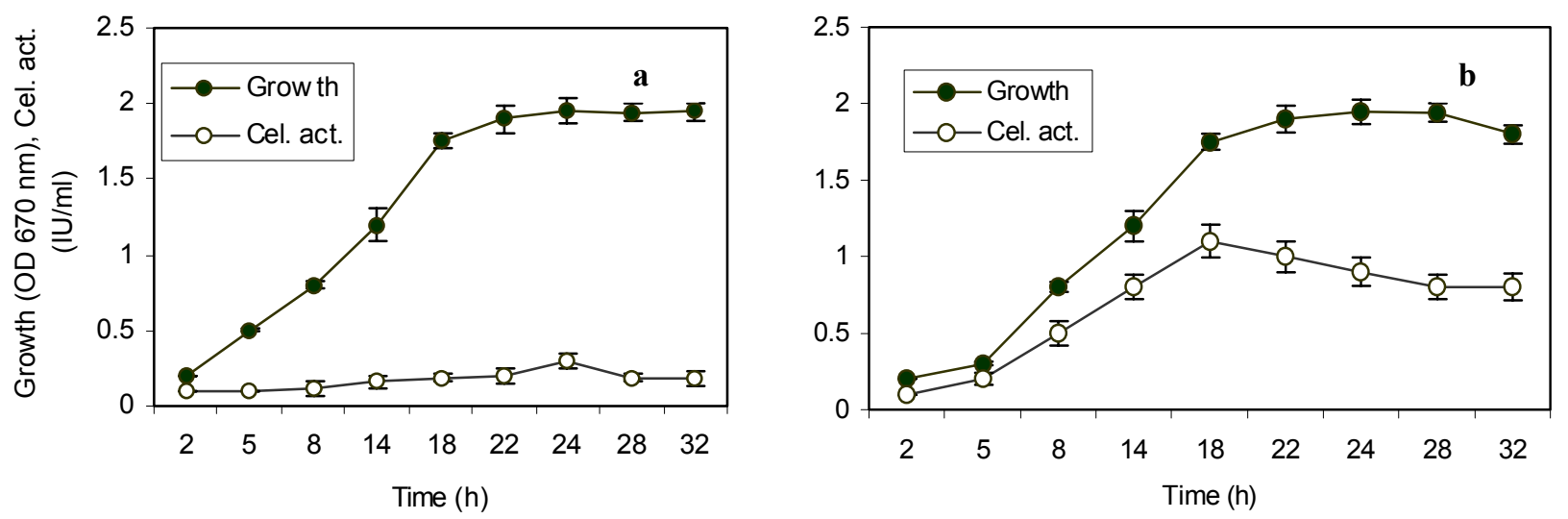

Figure 1. Growth and cellulase production by the wild strain of $B$. pumilus (a) and BpCRI 6 mutant (b). $0.2 \%$ (w/v) CMC was used to induce the enzyme synthesis within the strains. Cel.act: Cellulase activity.

Table 1. Effects of some chemical compounds on cellulase production by the wild type and BpCRI 6 mutant.

\begin{tabular}{|l|l|c|c|c|c|}
\hline \multirow{2}{*}{$\begin{array}{c}\text { Chemical } \\
\text { compound } \\
\text { treatment }\end{array}$} & \multirow{2}{*}{ Concentration } & \multicolumn{4}{|c|}{ Cellulase activity (IU/ml) } \\
\cline { 3 - 6 } & & \multicolumn{2}{|c|}{ WT } & \multicolumn{2}{c|}{ BpCRI 6} \\
\cline { 3 - 6 } & & CMC & Cellobiose & CMC & Cellobiose \\
\hline SC (control) & & $0.30 \pm 0.04$ & $0.15 \pm 0.01$ & $1.20 \pm 0.5$ & $0.85 \pm 0.06$ \\
\hline Ca2+ & $1 \mathrm{mM}$ & $0.39 \pm 0.05$ & $0.17 \pm 0.02$ & $1.90 \pm 0.6$ & $1.20 \pm 0.10$ \\
\hline EDTA & $1 \mathrm{mM}$ & $0.24 \pm 0.00$ & $0.00 \pm 0.00$ & $0.50 \pm 0.06$ & $0.22 \pm 0.03$ \\
\hline $\mathrm{NDP}$ & $1 \mathrm{mM}$ & $0.00 \pm 0.00$ & $0.00 \pm 0.00$ & $0.28 \pm 0.02$ & $0.10 \pm 0.01$ \\
\hline $\mathrm{Ca} 2+/ \mathrm{EDTA}$ & $1 \mathrm{mM} / 1 \mathrm{mM}$ & $0.20 \pm 0.00$ & $0.00 \pm 0.00$ & $0.30 \pm 0.06$ & $0.17 \pm 0.01$ \\
\hline $\mathrm{Ca}+/ \mathrm{NDP}$ & $1 \mathrm{mM} / 1 \mathrm{mM}$ & $0.00 \pm 0.00$ & $0.00 \pm 0.00$ & $0.15 \pm 0.05$ & $0.08 \pm 0.002$ \\
\hline
\end{tabular}

*The chemical compound treatments were carried out for $24 \mathrm{~h}$ to allow maximum cellulase production by the strains.

\section{Statistical analysis}

Data presented are the averages of three replicates $( \pm S E)$ obtained from three independent experiments. Analysis of variance for all data was carried out using SigmaStat 2.03 computer program.

\section{RESULTS}

\section{Cellulase production by the wild type and the mutant strain BpCRI 6}

After the chemical mutagenesis, a mutant strain $B p C R I 6$ was isolated for its ability to produce significant amounts of cellulase on agar plates. The selection of this cellulase-producing strain was based on the diameter of the clear zone surrounding the colonies on the platescreening medium. This screening step was found to give fairly reliable indication of exhibited cellulolytic activities. The BpCRI 6 clone and the wild type were further assessed in shaking flask cultures under conditions of catabolite repression. No significant differences were observed in the growth of both wild type and BpCRI 6 strain as shown in Figure 1. However, BpCRI 6 mutant exhibited significantly higher production of cellulase than the wild type strain under SC condition. This result indicates that the enhancement of cellulase production in $B p C R I 6$ is not due to an increase in cell growth but is only due to the chemical mutagenesis affecting the synthesis of cellulase within the strain.

The mutant strain $B p C R I 6$ secreted approximately four times more cellulase than the wild type when grown in SC conditions. As shown in Figure 1 the rate of the enzyme production in the medium was found to be stationary growth-phase dependent in the wild type and exponential growth-phase dependent in $B p C R / 6$. The optimum production of cellulase $(0.3 \mathrm{U} / \mathrm{ml})$ in the wild type appeared at $24 \mathrm{~h}$ of growth, while that of $B p C R / 6$ $(1.2 \mathrm{U} / \mathrm{ml})$ appeared at $19 \mathrm{~h}$ (Figure 1). Unlike the wild strain, BpCRI 6 exhibited an improved cellulase production within a shorter growth-time, and was therefore referred to as an improved strain for cellulase synthesis. The production of cellulase was enhanced in presence of $\mathrm{Ca}^{2+}(1.0 \mathrm{mM})$ but reduced in presence of EDTA and DNP (Table 1). DNP showed a higher inhibitory effect on cellulase synthesis followed by EDTA. 

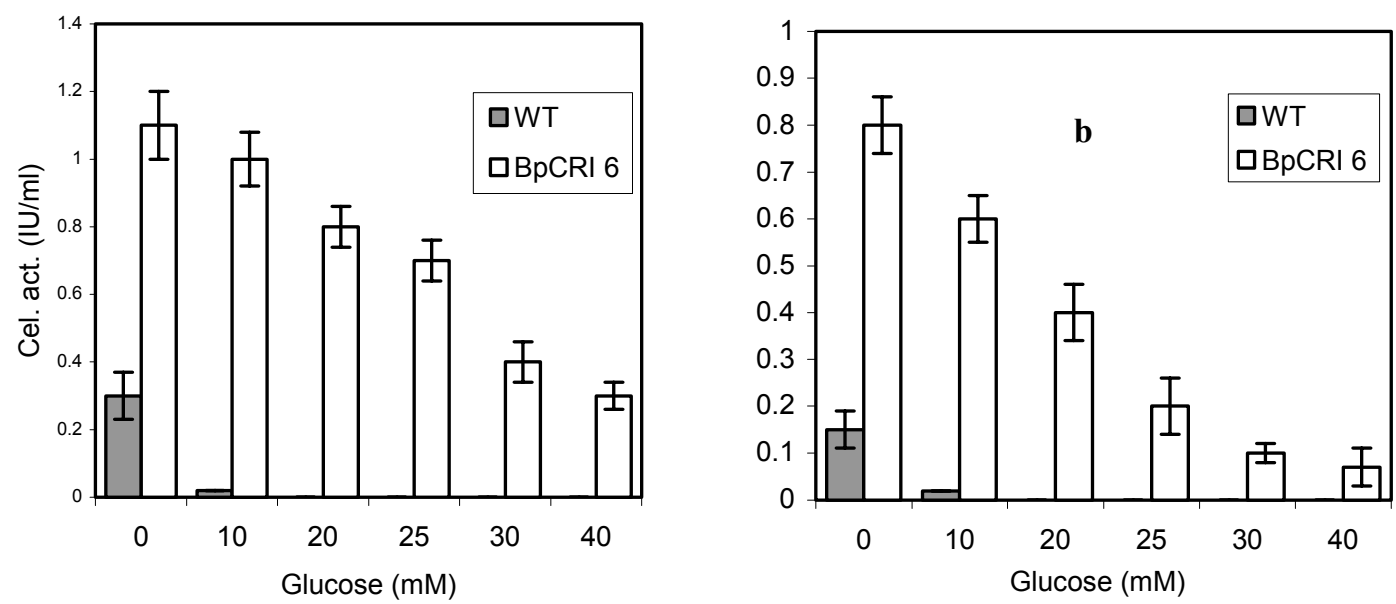

Figure 2. Production of cellulase under conditions of catabolite repression. a: Enzyme production in presence of $0.2 \%$ (w/v) $\mathrm{CMC}$ and different concentrations of glucose. b: Enzyme production in presence of $0.2 \%(\mathrm{w} / \mathrm{v})$ Cellobiose and different concentrations of glucose.

Table 2. Enhanced cellulase production under conditions of catabolite repression in a combined WT-BpCRI 6 strain community.

\begin{tabular}{|l|l|l|l|l|}
\hline \multirow{2}{*}{ Growth conditions* } & & \multicolumn{3}{|c|}{ Cellulase activity (IU/ml) } \\
\cline { 3 - 5 } & Substrates & WT & BpCRI 6 & WT + BpCRI 6 \\
\hline \multirow{S}{SC}{ (control) } & CMC & $0.30 \pm 0.08$ & $1.22 \pm 0.11$ & $2.25 \pm 0.18$ \\
\hline SC $+40 \mathrm{mM}$ & Cellobiose & $0.18 \pm 0.09$ & $0.81 \pm 0.09$ & $1.66 \pm 0.11$ \\
glucose & CMC & $0.00 \pm 0.00$ & $0.47 \pm 0.06$ & $0.98 \pm 0.08$ \\
\hline
\end{tabular}

*The cell cultures were incubated for $24 \mathrm{~h}$ to allow maximum cellulase production in the wild type.

\section{Cellulase production under catabolite repression}

Figure 2 shows the enzyme activity on $0.2 \%(w / v)$ CMC or cellobiose at different glucose concentrations. The cultures were incubated for $24 \mathrm{~h}$ to obtain an optimum production of the enzyme. At $10 \mathrm{mM}$ glucose concentration, the mutant strain $B p C R I 6$ exhibited approximately ten times higher activity on CMC than the wild type (Figure 2a), and approximately 6 times higher on cellobiose than the wild type (Figure 2b). These represent approximatively $80 \%$ of the mutant's ability to produce cellulase in the absence of glucose, which means that the mutant loses only $20 \%$ of its cellulase production ability under catabolite repression (Figure $2 a, b)$. At $20 \mathrm{mM}$ glucose concentration, no cellulase activity was detected in the wild type, indicating a complete repression of the enzyme synthesis, but $B p C R I$ 6 strain still produced significant amount of cellulase (0.9 $\mathrm{U} / \mathrm{ml}$ on $\mathrm{CMC}$, and $0.5 \mathrm{U} / \mathrm{ml}$ on cellobiose) under the same condition (Figure 2a,b). The production of cellulase was repressed in both wild type and BpCRI 6 under conditions of catabolite repression. Nevertheless, the level of repression in $B p C R I 6$ was significantly lower compared to that of the wild type (Figure 2). Interestingly, a higher cellulase activity was detected under condition of catabolite repression (40 $\mathrm{mM}$ glucose) when we combined the wild type and BpCRI 6 strain in the same culture (Table 2). We were able to double the production rate of cellulase through such stable microbial combination in presence of high concentration of glucose.

\section{Characterization of the cellulase produced by $B p C R I$ 6 and wild type}

The optimum $\mathrm{pH}$ for $\mathrm{BpCRI} 6$ enzymatic reaction was detected at $\mathrm{pH} 6.5$ (Figure 3a,b). When BpCRI 6 was stored overnight at $4{ }^{\circ} \mathrm{C}$ and at $\mathrm{pH}$ value between 6.0 and 6.5 , no loss of activity was observed (results not shown). Outside this $\mathrm{pH}$ values the enzyme activity dropped to 20 $\%$. The cellulase from $B p C R I 6$ displayed its optimum activity at $50^{\circ} \mathrm{C}$, which dropped to $80 \%$ at $70^{\circ} \mathrm{C}$ and further to $30 \%$ at $80^{\circ} \mathrm{C}$ both on $\mathrm{CMC}$ and cellobiose (Figure $3 \mathrm{c}, \mathrm{d}$ ). Comparatively, the wild type cellulase 

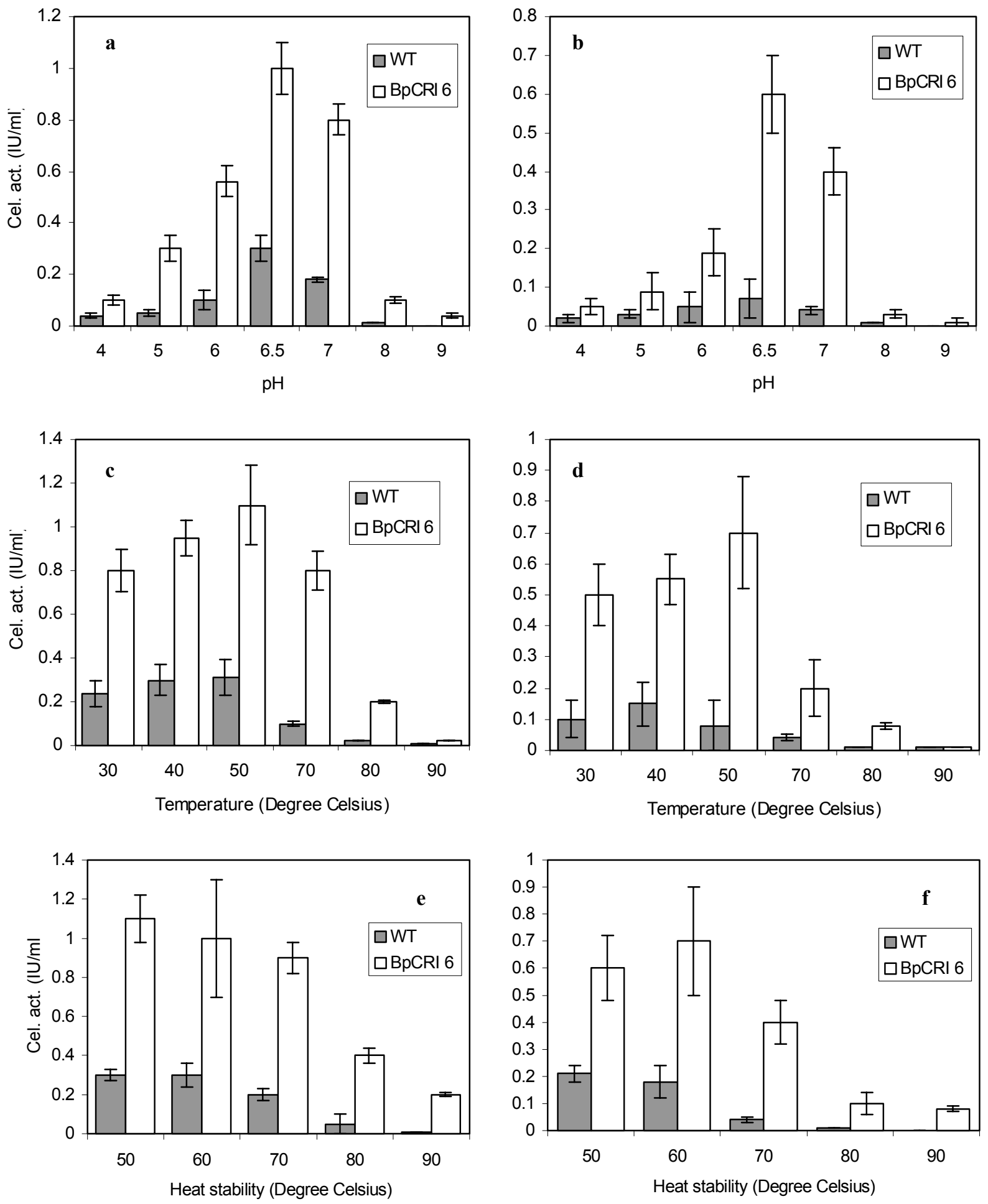

Figure 3. Optimum conditions for cellulase activity produced by BpCRI 6 and wild type. Optimum pH for the enzyme activity on CMC (a); and on cellobiose (b). Optimum temperature for the enzyme activity on CMC (c), and on cellobiose (d). Heat-stability of the enzyme and residual activity on CMC (e), and on cellobiose (f).

displayed similar biochemical characteristics (optimum $\mathrm{pH} 6.5$, optimum temperature $50^{\circ} \mathrm{C}$ ) to that of $\mathrm{BpCRI} 6$ strain (Figure 3 a,b,c,d). In optimum conditions (pH 6.5,
Temperature $50^{\circ} \mathrm{C}$ ), the purified enzyme from BpCRI 6 strain showed high activity toward CMC $(1.2 \mathrm{U} / \mathrm{ml})$ and relatively low activity toward cellobiose $(0.82 \mathrm{U} / \mathrm{ml})$. The 
thermostability of $B p C R I 6$ cellulase was studied for 15 min. Results show that $40 \%$ of the original activity was retained after heat treatment at $80^{\circ} \mathrm{C}$ while the wild type enzyme lost its activity under similar conditions (Figure 3 $e, f)$.

\section{DISCUSSION}

There have been many efforts to generate microorganisms with high ability to produce cellulase that can degrade native cellulose (Aristidou and Penttilä, 2000). However, no potential cellulase producers have been reported from the genus Bacillus to date. A mutant of $B$. pumilus obtained in this study produced promising amounts of cellulase and can therefore extend the cellulase producer families into the genus $B$.. This mutant $(B p C R I$ 6) presents several advantages such as high activity in presence of substrates like CMC and cellobiose and enhanced production of cellulase under catabolite repression. How EMS triggered the catabolite repression insensitivity in this mutant is not yet elucidated. To our knowledge, this is the first report on a successful cellulase producer mutant using $B$. pumilus. This is also very promising since most cellulase-producing organisms are under the control of catabolite repression (Coughlan, 1985; Hrmova et al., 1991). Further molecular studies on $B p C R I 6$ will be necessary to reveal the mutation.

The most widely used organisms for cellulase production, namely $T$. reesei have shown several disadvantages such as catabolite repression of the enzyme biosynthesis due of cellobiose, and deficiency in $\beta$-glucosidase (cellobiase) leading to accumulation of cellobiose (Durand et al., 1988). However, BpCRI 6 mutant produces significant amounts of cellobiase, which can be further improved by controlled culture conditions and genetic approaches. A mixture of culture containing a cellulolytic and a noncellulolytic strain has been reported to be the best condition for degrading cellulose (Lewis et al., 1988). As demonstrated in Table 2, we observed an improvement in cellulase synthesis in a combined wild type-BpCRI 6 culture. We therefore suggest that a combined microbial community of $B p C R I 6$ strain and a well-known cellulase producer such as $T$. reesei could be a promising way to alleviate completely the catabolite repression and thereby achieving a higher biodegradation efficiency for natural cellulosic materials. In addition, mutant $B p C R I 6$ has proved to be very stable, showing little or no reversion, and grows rapidly in both liquid and solid media.

Most research has been focused on controlled culture conditions leading to significant amount of the enzyme synthesis. Only few data are available on the signalling transduction mechanisms leading to upregulation of cellulase encoded genes. The enzyme synthesis by $B p C R I 6$ was increased under $\mathrm{Ca}^{2+}$ treatment and considerably reduced under DNP and EDTA (Table 1).
We suggest from these findings that overexpression of the cellulase genes within this strain could be under the control of $\mathrm{Ca}^{2+}$-channel signalling pathways. EDTA is a known metal-complexing agent chelating inorganic groups such as $\mathrm{Ca}^{2+}$ and thereby reducing the production ability of the organism. DNP however, has been reported as an uncoupler for oxidative phosphorylation (Ali and Sayed, 1992) indicating that a series of phosphorylation/dephosphorylation steps might play a crucial role in signalling transduction leading to cellulase synthesis in the mutant. The involvement of $\mathrm{Ca}^{2+} /$ calmodulin-dependent kinase in the transcription and secretion of endoxylanase II in $T$. reesei (March et al., 1998) supported our findings indirectly. These data point to the involvement of probable phosphorylation cascade mediating the transcription machinery of the cellulase gene. As little is known on how EMS triggered the upregulation of the enzyme synthesis, research in this field would make a major contribution to improve the production rate of cellulase particularly in this strain and in bacteria in general.

\section{ACKNOWLEDGEMENTS}

The authors would like to thank Dr. B. Omafuvbe for providing us with the wild strain of $B$. pumilus. The experiments described in this report comply with the current laws guiding the research rules and regulations of the country in which this work was performed.

\section{REFERENCES}

Ali S, Sayed A (1992). Regulation of cellulase biosynthesis in Aspergillus terreus. World J. Microbiol. Biotechnol. 8:73-75.

Aristidou A, Penttilä M (2000). Metabolic engineering applications to renewable resource utilization. Curr. Opin. Biotechnol. 11:478-483.

Bhat MK, Bhat S (1997). Cellulose degrading enzymes and their potential industrial applications. Biotechnol. Adv. 15:583-620.

Coughlan MP (1985). The production of fungal and bacterial cellulases with comment on their production and application. Biotechnol. Genet. Eng. Rev. 13:39-109.

Durand H, Clanet M, Tiraby G (1988). Genetic improvement of T. reesei for large scale cellulase production. Enzyme Microb. Technol. 10:341-346.

Espana AL, Torres C, Pastor FIJ, Blanco A, Roncero MaB, Colom JF et al., (1998). Enzymatic modifications of wheat straw fibers and handsheet properties. In: $7^{\text {th }}$ International conference on Biotechnology in the Pulp and Paper Industry. Vancouver, June 1619. Vol. C, pp. 127-130.

Feng YY, Yang WB, Ong SL, Hu JY (2001). Fermentation of starch for enhanced alkaline protease production by constructing an alkalophilic Bacilus pumilus strain. Appl. Microbiol. Biotechnol. 54:153-160.

Hong H-B, Chang Y-S, Choi S-D, Nam I-H, Lee Y-E (2001). Isolation and characterization of a cell-associated protein of Bacillus pumilus PH-01. Appl. Microbiol. Biotechnol. 56:402-405.

Hrmova M, Petrakova E, Biely P (1991). Introduction of cellulose and xylan-degrading enzyme system of Aspergillus terreus by homo and heterodisaccharides composed of glucose and xylose. J. Gen. Microbiol. 137:541-547.

Kibblewhite PR, Clark TA (1996). Enzymatic modification of radiata pine 
kraft fibre and handsheet properties. Appita J. 49:390-396.

Kotchoni OS, Shonukan OO (2002). Regulatory mutations affecting the synthesis of cellulase in B. pumilus. World J. Microbiol. Biotechnol. 18:487-491.

Labudova I, Farkas V (1983). Enrichment technique for the selection of catabolite repression-resistant mutants of $T$. as producers of cellulase. FEMS Microbiol. Lett. 20:211-215.

Lamed R, Bayer EA (1988). Cellulosomes from Clostridium thermocellum. Methods Enzymol. 160:472-481.

Lewis SM, Montgomery L, Garleb KA, Berger LL, Fahey GCJr (1988). Effects of alkaline hydrogen peroxide treatment on in vitro degradation of cellulosic substrates by mixed ruminal microorganisms and Bacteroides succinogenes S85. Appl. Environ. Microbiol. 54:1163-1169.

Lin M, Kilburn DG, Breuil C, Robertson AG (1995). Assessing changes in the specific surface area of kraft papermaking fibres with cellulase binding domain. In: $8^{\text {th }}$ International Symposium on Wood and Pulping Chemistry. Helsinki, June 6-9. Vol. 1, pp. 645-652.

March RL, Zeilinger S, Kristufek D, Kubicek CP (1998). Ca ${ }^{2+}$-calmodulin antagonists interfere with xylanase formation and secretion in $T$. reesei. Biochem. Biophys. Acta 1403:281-289.

Nuyens F, VanZyl HW, Iserentant D (2001). Heterologous expression of the Bacillus pumilus endo- $\beta$-xylanase (xynA) gene in the yeast Saccharomyces cerevisiae. Appl. Mricrobiol. Biothechnol. 56:431434.

Ohara H, Karita S, Kimura T, Sakka K, Ohmiya K, (2000). Characterization of the cellulolytic complex (cellulosome) from Ruminococcus albus. Biosci. Biotechnol. Biochem. 64:254-260.

Omafuvbe B (1998). Microbiological and biochemical changes during the fermentation of soyabeans for "soydadawa". PhD thesis, Microbiology Department, Obafemi Awolowo University, lle-lfe, Nigeria.
Oksanen T, Pere J, Paavilainen L, Buchert J, Viikari L (2000). treatment of recycled kraft pulps with $T$. reesei hemicellulases and cellulases. J. Biotechnol. 78:39-48.

Pastor FIJ, Pujol X, Blanco A, Vidal T, Torres AL, Diaz P (2001). Molecular cloning and characterization of a multidomain endoglucanase from PeaniB. sp. BP-23. Evaluation of its performance on pulp refining. Appl. Microbiol. Biotechnol. 55:61-68.

Roncero MaB, Torres AL, Colom JF, Vidal T (2000). Effects of xylanase treatment on fibre morphology in totally chlorine free bleaching (TCF) of Eucalyptus pulp. Process Biochem. 36:45-50.

Schwarz WH (2001). The cellulosome and cellulose degradation by anaerobic bacteria. Appl. Microbiol. Biotechnol. 56:634-649.

Solomon BO, Amigun B, Betiku E, Ojumu TV, Layokun SK (1997). Optimization of cellulase production by Aspergillus flavus Linn isolate NSPR101 grown on bagasse. J. Niger. Soc. Chem. Eng. 16:61-68.

Somogyi N (1944). A photometric adaptation of the Somogyi method for the determination of glucose. J. Biol. Chem. 153:375- 380.

Suurnäkki $A$, Tenkanen $M$, Siika-aho $M$, Niku Paavola M-L, Viikari L. Buchert J (2000). T. reesei cellulases and their core domains in the hydrolysis and modification of chemical pulp. Cellulose 7:189-209.

Torres AL, Roncero MaB, Colom JF, Pastor FIJ, Blanco A, Vidal T (2000). Effect of a novel enzyme on fibre morphology during ECF bleaching of oxygen delignified eucalyptus kraft pulps. Bioresour. Technol. 74:135-140.

Weimer P, Weston, W (1985). Relationship between the fine structure of native cellulose and cellulose degradability by the cellulase complexes of $T$. reesei and Clostridium thermocellum. Biotechnol. Bioeng. 27:1540-1547. 